\title{
Trends of eye lid carcinoma in Chhattisgarh state of India and their outcome with high dose interstitial brachytherapy
}

\author{
${ }^{1}$ Kerketta M, ${ }^{2}$ Rathore VB, ${ }^{3}$ Choudhary V, ${ }^{4}$ Azad SK \\ ${ }^{1}$ Dr. Manjula Kerketta, Assistant Professor, ${ }^{2}$ Dr Vikram Bali Rathore, PhD, Assistant Professor, Medical Physics, ${ }^{3}$ Dr. \\ Vivek Choudhary, Director-cum-Professor, ${ }^{4}$ Dr. Surendra Kumar Azad, Professor, Department of Radiotherapy, Pt. J. N. \\ M. Medical College and Regional Cancer Centre, Jail Road Raipur Chhattisgarh, India
}

Address for correspondence: Dr. Manjula Kerketta, email: manjula.raipur@gmail.com

\begin{abstract}
Introduction: Sight is the most precious of all senses. Tumors of the eye and orbit can be life threatening and causes blindness and disfiguring. In planning management the threat to life with disfigurement is the primary issue to be faced with, the best treatment aimed is to cure and long term control having priority. With this aim our study is to report the trend of eyelid cancer in Chhattisgarh state of India and their outcome with High Dose Rate Interstitial Brachytherapy. Material and Methods: Thirty Six Patients with histo-pathologically confirmed malignant eyelid tumours previously untreated and registered at the Department of Radiotherapy, Pt. J.N.M. Medical College and Regional Cancer Centre, Raipur, were considered in the present study. Registered patients were classified to find out general trend of occurrence in Chhattisgarh, India. Post- treatment patients were reviewed for five years to study the outcome of high dose rate interstitial brachytherapy (HDRIBRT) of eyelid cancer. Results and Discussion: Male predominance was seen in the patients of eyelid tumors. The occurrence of eyelid tumour was found higher $(72.2 \%)$ in the patients with age above 60 years and $27.8 \%$ were less than 60 years old. Anatomically majority of malignancies found in upper eyelid than lower eyelid. Post Treatment follow up ranged from 10 months to 5 years in which all the patients remained locally controlled. Conclusions: Histo-pathologically SCC predominantly found in males than female. The excellent results of interstitial brachytherapy prove that it may be one of the efficient modality for the treatment of carcinoma eyelid.
\end{abstract}

Key words: Eyelid Cancer, Interstitial Brachytherapy, Squamous Cell Carcinoma, Toxicity.

\section{Introduction}

Cancer of the eye lid accounts for $5-10 \%$ of all skin cancer with $90 \%$ being basal cell carcinoma [1]. Among the Indian population, squamous and adenocarcinoma involving the tarsal glands are more common, incidence ranging between $2.4 \%$ to $30.2 \%$ of all malignant eye lid tumours [2]. They are more aggressive and invasive then basal cell carcinoma and have a definite metastatic potential. If treatment is delayed they can invade the orbital and intracranial structures and hence have a considerable potential for mortality and morbidity [3]. Eye lid cancer is a therapeutic challenge due to the cosmetic and functional implications of this anatomical region and the objectives of therapy are tumour control functional and cosmetic outcomes. A variety of approaches are available including surgical resection, curettage, electro dissection, Mohs micrographic

Manuscript received: $2^{\text {nd }}$ July 2015

Reviewed: $11^{\text {th }}$ July 2015

Author Corrected: $20^{\text {th }}$ July 2015

Accepted for Publication: $5^{\text {th }}$ Aug 2015 surgery, cryotherapy, photodynamic therapy, laser ablation and radiotherapy [4]. Surgery is the most commonly used treatment modality. External beam radiotherapy [EBRT] has been employed mainly in unresectable or inoperable cases [5]. Brachytherapy may represent an attractive option providing a high local cure rate with functional and cosmetic results comparable to surgery for orbital and eyelid tumours [610]. In the present study we are sharing our experience with 36 patients treated with interstitial High Dose Rate (HDR) brachy therapy with the aim to report the trend of eyelid cancer in Chhattisgarh state of India and their outcome with High Dose Rate Interstitial Brachytherapy treatment.

\section{Material and Methods}

Thirty Six Patients with histo-pathologically confirmed malignant eyelid tumours previously untreated and registered at the Department of Radiotherapy, Pt. 
J.N.M. Medical College and Regional Cancer Centre, Raipur, Chhattisgarh, India were considered in the present study. Registered patients were classified with respect gender, age and tumour localization to find out general trend of occurrence in Chhattisgarh, India.

All patients were examined and investigated with routine hematological \& biochemical examinations and X-ray chest before starting radiotherapy treatment. In Operation theatre, treatment area was marked on patient. Under general anesthesia rigid hollow and open ended stainless steel needles were inserted into the tumor area parallel to each other in single plane. The spacing between two needles were $1 \mathrm{~cm}$. Plastic tubes were then threaded into these hollow needles and left in place to cover the entire target area with subsequent removal of metal needles. The plastic tubes were then secured in close proximity to skin with plastic buttons. Wet cotton gauge were used for posterior packing to provide gap between the target and eye structure.

Treatment planning and dose calculation were done with Plato Sun Rise Treatment Planning System (Nucletron, The Netherlands). The prescribed dose was optimized in the defined dose points oriented to cover desired volume. Dwell position and dwell time were optimized with dose point optimization method to achieve desired dose distribution. All patients were planned for 32.5Gy (Gray) with 6.5Gy per fraction daily for continuous five days.

After planning completion and evaluation, the patients were shifted to brachytherapy treatment room. Applicators were connected to Microselectron High Dose Rate brachytherapy machine through transfer tubes and optimized plans were executed. After completion of the treatment the applicators were removed under all aseptic precaution in Operation Theater (OT). No complications were seen during procedure.

All the patients were reviewed weekly for one month to observe acute radiation toxicities and then monthly for one year for the assessment of response and treatment related complications. Quarterly assessments were done for next three years and half yearly in the subsequent years for routine checkups and ophthalmic examination, to find out the outcome with high dose rate interstitial brachytherapy (HDRIBRT) treatment.

\section{Results}

A total thirty six patients were analyzed, out of them 23 were male and 13 were female. Male predominance was seen in the patients of eyelid tumors. The age of the patients ranged from 35 to 72 years with median age 60 years. The occurrence of eyelid tumour was found higher $26(72.2 \%)$ in the patients with age above 60 years and $10(27.8 \%)$ were less than 60 years old. Patients with right eye were $72.2 \%$ while $27.8 \%$ in left eyes. Anatomically majority of malignancies found in upper eye lid (22/36) than lower eye lid (14/36). Figure-1 shows the distribution of eyelid tumours with respect to gender, age of the patients and localization of tumours.

Figure 1: Distribution of malignant eye lid tumours with respect to gender, age and localization

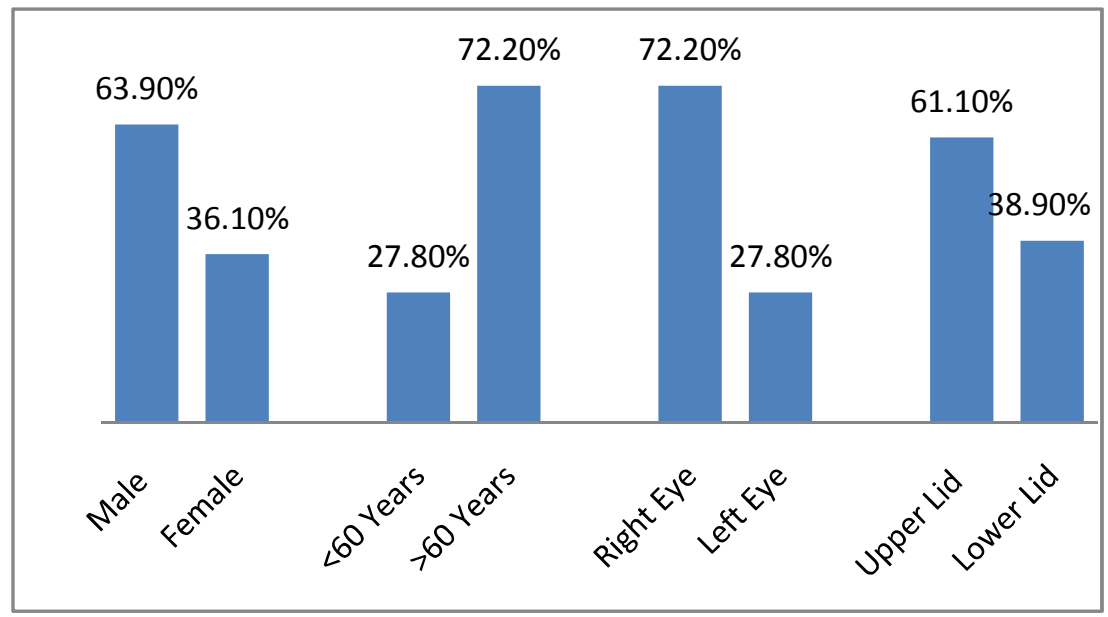

Histo-pathological analysis shows that Squamous Cell Carcinoma (SCC) predominance over Basal Cell Carcinoma (BCC) and Sebaceous Gland Carcinoma (SGC) in upper eyelid tumours while BCC predominance over SCC and SGC in 
lower eyelid malignancies. Over all Histo-pathological analysis of all eye lid tumours reveals that SCC is more common type of malignancy than BCC and SGC. Figure-2 shows the histo-pathological distribution of eyelid tumours.

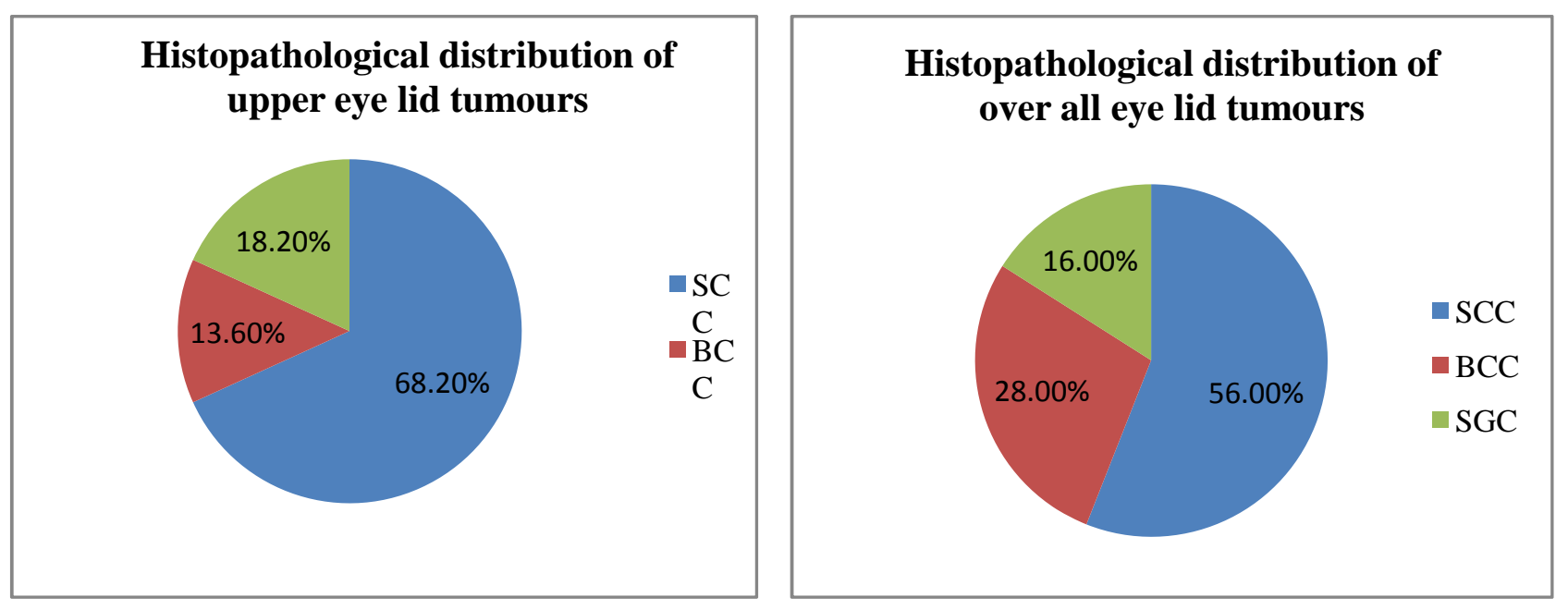

Post Treatment follow up ranged from 10 months to 5 years in which all the patients remained locally controlled. The median follow up was 46 months. Local control was calculated from end of treatment to the last follow up. The acute toxicities were graded according to RTOG (Radiation Therapy Oncology Group) and the late toxicities according to CTCAE (Common Terminology Criteria for adverse Event). Local control and good functional results were achieved in all patients. Acute side effects noted were erythema, odema, congestion and loss of eye lashes. Late side effects were radiation fibrosis on implanted area and vitiligo. Post brachytherapy followup summary of patients with eye lid tumours are summarised in table-1.

Table-1: Post brachytherapy followup summary of patients with eye lid tumour

\begin{tabular}{|c|c|c|c|c|c|c|}
\hline S.N. & Clinical Parameters & 1month & 3month & 1 Year & 2 Year & 5 Year \\
\hline 1 & $\begin{array}{l}\text { Persistence of Acute } \\
\text { side effect. }\end{array}$ & $\begin{array}{l}3 \text { cases out } \\
\text { of } 36\end{array}$ & Nil & Nil & Nil & Nil \\
\hline 2 & Dimension of vision & Nil & Nil & Nil & Nil & Nil \\
\hline 3 & Funds Change & Nil & Nil & Nil & Nil & Nil \\
\hline 4 & Cosmetic appearance & $\begin{array}{l}\text { Acceptable } \\
36 / 36\end{array}$ & $\begin{array}{l}\text { Good } \\
36 / 36\end{array}$ & $\begin{array}{l}\text { Vitilgo loss of } \\
\text { eyelashes } 36 / 36\end{array}$ & $\begin{array}{l}\text { Vitiligo Loss of } \\
\text { eyelashes } 36 / 36\end{array}$ & $\begin{array}{l}\text { Vitiligo loss of } \\
\text { eyelashes } 36 / 36\end{array}$ \\
\hline 5 & $\begin{array}{l}\text { Functional } \\
\text { Impairment }\end{array}$ & Nil & Nil & Nil & Nil & Nil \\
\hline 6 & Recurrence & Nil & Nil & Nil & Nil & Nil \\
\hline 7 & Patients Satisfaction & Good & Good & Good & Good & Good \\
\hline
\end{tabular}

Note: In three patients there were erythema, edema and congestion of the eye for one month. Cosmetically wound healing was acceptable for all patients for one month and good recovery of scar were found in all patients after three month. Late effect Vitiligo losses of eyelashes were found in all patients after one year till last follow up.

\section{Discussions}

Eyelid tumours are relatively rare entity representing 3-5\% of all epithelial tumours of the facial skin [11]. The three distinct types of eyelid cancers with their variable local and distant invasion rate coupled with surrounding critical visual apparatus have always posed a challenge towards the effective management. While BCCs are locally recurrent, SCCs are more aggressive and invasive and SGC also have high distant failure rate [11-13]. The Chhattisgarh state almost covered with forest and rural area with economically lower and middle class population. Males are the primary earning person and they need to work in the field, hence likely to expose with sun light and other carcinogenic agents present in the 
environment, which may lead to the male dominancy in eyelid carcinoma which is similar to the finding by Donaldson et al. The distinct male predominance $64.7 \%$ vs $35.3 \%$ may represent increased occupational sunlight exposure by males rather than a genetic predisposition [14]. Numbers of patients with carcinoma of right eye were found higher than left eyes, which is similar to other studies [15]. Previous studies reveal IBRT a most powerful modality for good cosmetic and local control result. Table-2 shows the comparison of local control after brachytherapy. Daly et al [16] and Conill et al [17] reported $97.4 \%$ and $91.6 \%$ local control with good function results respectively. Similar results had been reported by Gambro et al (96\%) [18] and Azad et al (90\%) [3]. Results of the present study are towards the better aspect of the IBRT for eyelid carcinoma in which almost all patients achieved good cosmetic and local control. Queensland has the highest incidence of cutaneous SCC in the world [19], which is similar to the finding of the present study and other series too $[20,21]$.

Table-2: Comparison of local control after $\mathrm{Ir}^{-192}$ brachytherapy for carcinoma of Eyelid

\begin{tabular}{|l|l|l|l|l|}
\hline S.No. & Author & Number of patients & Follow up & Local Control \\
\hline 1 & Daly -1984 [7] & 165 & 5 years & $97 \%$ \\
\hline 2 & Gambaro 2001 [11] & 50 & Median 82 months & $96 \%$ \\
\hline 3 & Conill C 2004 [12] & 24 & Mean 43 months & $91.6 \%$ \\
\hline 4 & Azad S K 2011 & 20 & Median 39.5 months & $90 \%$ \\
\hline
\end{tabular}

\section{Conclusions}

The finding of the current study reveals that the general trend of eye lid tumours in centrally located state Chhattisgarh, India was found to be histopathologically SCC predominantly in males than female. The excellent results of interstitial brachytherapy prove that it may be one of the efficient modality for the treatment of carcinoma eyelid.

\section{Acknowledgements:}

The authors would like to thanks Dr. A. K. Chandrakar, Dean, Pt. J.N.M. Medical College, Raipur, for his continuous encouragement and support for this study.

\section{Funding: Nil}

\section{Conflict of interest: Nil}

\section{Permission from IRB: Yes}

\section{References}

1. Cooke BE Jr, Bartley GB. Treatment options and future prospects for the management of eyelid malignancies and evidence based update. Opthalmology. 2001 Nov; 108(11):2088-98, quiz 2099100,2121 .

2. Dailey Jr, Kennedy RH, Flaharty PM et al. Squamaous cell carcinoma of eye lid. Ophthal Plast Reconstr, Surg. 1994 Sep; 10(3):153-9.

3. Azad SK, Choudhary V. Treatment results of high dose rate interstitial Brachytherapy in carcinoma of eyelid. J Cancer Res Ther. 2011 July; 7(6):157-61.
4. Murchison AP, Wallrath JD, Washington CV. Non surgical treatment of primary non-melanoma eyelid malignancies: A review. Clin Experiment Ophthalmol.2011 Jan; 39(1): 65-83, quiz 92-3.

5. Conill C, Sanchez-Reyes A, Molla M, Vitalta A. Brachytherapy with Ir-192 as treatment of carcinoma of the tarsal structure of the eyelid. Int. J Radiat Oncology Bio. Phys. 2004 Aug; 1;59 (5):1326-9.

6. Avril MF, Auperin A, Margulis A, et al. Basal cell carcinoma of the face: Surgery or Radiotherapy? Results of a randomized study. Br J Cancer. 1997; 76(1):100-6.

7. Daly NJ, De Lafontan B, Combes PF. Results of the treatment of 165 lid carcinomas by iridium wire implant. Int J Radiat Oncol Biol Phys. 1984 Apr; 10(4):455-9.

8. Rio E, Bardet E, Ferron C et al. Interstitial Brachytherapy of periorificial skin carcinomas of the face: A retrospective study of 97 cases. Int J Radiat Oncol Biol Phys. 2005 Nov 1; 63(3):753-7. Epub 2005 May 31.

9. Stannard C, Maree G, Munro R et al. Iodine-125 orbital Brachytherapy with a prosthetic implant in situ. Strahlenther Onkol 2011 May;187 (5):322-7. doi 10. 1007/s 000-011-2177-y. Epub 2011 April26. 
10. Willich N. Technical and methodical developments of radiation oncology from a physician's point of view. Strahlenther Onkol. 2012;188(3):253-2. doi 10. 1007/s 00066-012-0190-4.

11. Petsuksiri J, Frank SJ, Garden AS et al, Out comes after radiotherapy for squamos cell carcinoma of the eyelid. Cancer 2008 Jan;112(1):111-8. doi: 10.1002/cncr.23143.

12. Reifler DM, Hornblass A. Squamos cell carcinoma of the eye lid. Surv. Opthalmol. 1986 May-Jun;30 (6) :349-5.

13. Murchison AP, Walrath JD, Washington CV. Nonsurgical treatments of primary, non-melanoma eye lid malignancies: A review. Clinical Experiment Ophthalmol. 2011 Jun; 39(1) : 65-3. quiz 92-3.doi 10.1111/j 1442-9071.2010.02422.x. epub 2011Jan 31.

14. Donaldson MJ, Sullivan TJ, Whitehead KJ and Williamson. Squamos cell Carcinoma of the eyelids. Br. J. Ophthalmol. 2002 Oct; 86 (10):1161-5.

15. Wong VA,Marshall JA, Whitehead KJ et al. Management of periocular basal cell carcinoma with frozen section controlled excision. Opthal Plast Reconst Surg 2002 Nov; 18 (6): 430-5.
16. Daly NJ, De Lafotan B, Combes PF. Results of the treatment of 165 lid carcinomas by Iridium wire implant. Int J Radiat Oncol Biol Phys 1984 April;10 (4):455-9.

17. Conill C, Molla M, Vilalta A Brachytherapy with ${ }^{192} \mathrm{Ir}$ as treatment of carcinoma of the tarsal structure of eyelid. Int J Radiat Oncol boil Phys 2004 Aug; 59 (5):1326-9.

18. Gambaro G, Negri E, Prino et al. Interstitial Brachytherapy with Iridium-192 for carcinomas of the eyelid and inner canthus. Radiother Oncol. 2001; 60(1) (Suppl.1):15- 6. doi 10.1016/s 0167-8140 (01) 80054-2.

19. Green A. Changing patterns in incidence of nonmelanoma skin cancer. Epith Cell Biol. 1992 Jan;1 (1):47-1.

20. Doxanas MT, Jackson-Iliff W, Iliff NT, et al. squamous cell carcinoma of the eyelids. Opthalmology. 1987May; 94 (5):539-1.

21. Francis IC, Benecke PS, Kappagoda MB. A ten year hospital survey of eyelid cancer. Aust J Opthalmol. 1984 May; 12 (2):121-7.

\section{How to cite this article?}

Kerketta M, Rathore VB, Choudhary V, Azad SK. Trends of eye lid carcinoma in Chhattisgarh state of India and their outcome with high dose interstitial brachytherapy. Int J Med Res Rev 2015;3(7):712-716. doi: 10.17511/ijmrr.2015.i7.134. 